\title{
SPELLING AND TRANSLITERATION
}

The text contains numerous Sinhalese, Pali and Sanskrit words. Where exact equivalents are available, the choice of a term of one language in preference to that of another generally depends on the context in which the given term occurs and the source on which the discussion is based. An exception to this rule is the few instances where Sanskrit forms (e.g., nirvana, karma) have secured a place in English usage.

Romanization follows the standard system of transliteration-common to all three languages-which is used in scholarly literature. A term which is expressed in the plural appears either in its original plural form (e.g., vibäragam) or in the original singular with an $s$ added at the end (e.g., gaṇinnānses).

For most of the terms used, conventional or approximate English equivalents are given. The English term monk, unless otherwise specified, is used to denote bhikkhu (ordained monk) as well as sämanera (novice).

Place names are generally given in the forms in which they are known today in Sinhalese. Where there are minor differences between the midtwentieth-century and nineteenth-century usages, the latter has been preferred (e.g., Huduhumpola and Pilimatalavva in preference to Suduhumpola and Pilimatalāva respectively). Some of the well-established Europeanized names, such as Colombo (= Kolamba) and Kandy (= Maha Nuvara), have been retained; others (e.g., Cotta $=$ Kōtțe, Cotton China $=$ Koțahēna) which are no longer in general usage have been dispensed with except from quotations and from bibliographical references if the Europeanized name appears on the title page.

With regard to personal names: the names of all monks have been 
viii

transliterated, as have the personal names of most laymen, but not all. The exceptions are those who wrote in English frequently or whose names appear in English documents in the same forms as they themselves wrote them, for example, Gooneratne (= Guṇaratna), Wijesinha (= Vijēsimina). 